\title{
TRADISI TAHLIL SEBAGAI TRADISI KULTURAL Fenomena Keberterimaan Tahlil Dalam Masyarakat Multikultural
}

\author{
Rudy Kurniawan \\ Dosen Universitas Sriwijaya \\ Pos-el: kur_nia_one@yahoo.co.id
}

\begin{abstract}
The purpose of this study describes children born with special needs or Down syndrome. Having characteristics that are easily recognized as mental retardation (mental retardation), visual impairment (visual impairment), hearing impairment (hearing impairment), hearing impairment (disability). Seen as a useless person. Not many people know that they can also be independent and excel. By looking at the communication of parents of children with Down syndrome. With a qualitative descriptive method, this study uses the Applied Behavior Analysis (ABA) Theory from Ivar O. Lavav which can change deviant behavior to control the behavior of children with Down syndrome. manage habitual problems and teach the skills needed by accepting communication and behavior in the family. The author observes a child with Down syndrome by interviewing his parents coupled with seeing the achievements that can be achieved by children with Down Syndrome. It turns out that the success of a child with Down syndrome in their daily lives is included in life activities, is introduced like a normal person, is responded to and respected. With love and patience communication and training in areas of interest, can make children with Down syndrome independent, achievers and can even make the nation proud.
\end{abstract}

Keywords: Communication, down syndrome

\begin{abstract}
Abstrak: Tujuan penelitian ini menggambarkan Anak yang dilahirkan dengan berkebutuhan khusus atau down syndrome. Memilik karakteristik yang mudah dikenali dengan sebutan tunagrahita (hambatan mental), tunanetra (hambatan penglihatan), tunarungu (hambatan pendengaran), tunadaksa (cacat tubuh). Dipandang sebagai orang yang tidak berguna. Belum banyak yang mengetahui bahwa mereka ini juga dapat mandiri dan berprestasi. Dengan melihat Komunikasi orangtua terhadap anak penderita down Syndrom. Dengan metode deskriptif kualitatif, penelitian ini menggunakan Teori Applied BehaviourAnalysis (ABA) dari Ivar O.Lavass yangdapat mengubah perilaku menyimpang untuk mengontrol perilaku anak down syndrome. mengatur masalah kebiasaan dan mengajarkan kemampuan yang diperlukan dengan menerima cara komunikasi dan perilaku dalam keluarganya. Penulis mengamati seorang anak down syndrome dengan mewawancarai orangtuanya ditambah dengan melihat prestasi-prestasi yang dapat diraih anak-anak down syndrom. Ternyata keberhasilan anak down syndrome kesehariannya diikutsertakan dalam aktivitas kehidupan, dikenalkan layaknya orang normal, direspon dan dihargai. Dengan komunikasi kasihsayang dan kesabaran serta latihan bidang yang diminati, dapat menjadikan anak down syndrome mandiri, berprestasi bahkan dapat mengharumkan nama bangsa.
\end{abstract}

Kata Kunci:Komunikasi, down syndrome

\section{PENDAHULUAN}

Semua orangtua menginginkan anaknya lahir normal. Namun diantaranya ada yang lahir dengan kebutuhan khusus. Ia memiliki keterbatasan baik secara fisik maupun nonfisik. Anak ini memiliki hambatan fisik dan mental yang menganggu pertumbuhan dan perkembangannya. Maka diperlukan penanganan khusus. Disebut dengan anak penyandang cacat. 
Anak ini dikategorikan anak dengan tunagrahita(mengalami hambatan pada mental), tunanetra (mengalami hambatan pada penglihatan), tunarungu(mengalami hambatan pada pendengaran), tunadaksa (mengalami cacat tubuh), attention deficit and hyperactivity disorder (perilaku hiperaktif), autis, down syndrome, dan tunaganda (memiliki lebih dari satu hambatan). Masing-masing memiliki karakteristik yang berbeda dan memerlukan penanganan dan pelayanan yang berbeda juga.

Walaupun demikian, anak pada kategori berkebutuhan khusus bukanlah berarti sumber daya manusia yang tak berarti. Banyak dilihat dalam media massa ada yang berhasil pada minatnya masing-masing. Oleh karena itu, menurut penulis harus juga ikut ditingkatkan kualitasnya. Mereka harus mandiri dan dapat berperan aktif dalam kehidupannya. Mereka perlu dikenali dan mendapat pelayanan khusus secara medis, pendidikan dan pelatihan. Agar layak hidupnya.

Anak berkebutuhan khusus ialah anak yang menderita downsyndrome. Down syndrome adalah kondisi keterlambatan perkembangan anak, dan kadang mengacu padaketidaksempurnaan terhadap mental.Down syndrome ditandai oleh kelainan jiwa atau cacat mental mulai dari yang sedang sampai yang berat, tetapi hampir semua anak yang menderita kelainan ini dapat belajar membaca dan merawat dirinya sendiri.

Secara umum, penderita down syndrome mudah dikenali dengan adanya penampilan fisikyang menonjol berupa bentuk kepala yang agak kecil, yaitu wajah khas dengan mata sipit yang membujur keatas. Jarak antara kedua mata berjauhan dengan tampak sela hidung yang rata dan datar (seperti mongol). Hidung kecil, mulut mengecil dengan lidah yang besar sehinggah cenderung dijulurkan keluar. Gambaran telapak tangan tidak normal yaitu terdapat satu garis besar melintang. Masalah intelegensi pada penderita down syndrome bervariasi dari retardasi ringan sampai sedang dengan nilai IQ berkisar dari 25-70 (Hull \& Jhonston: 2008).

Dalam pengamatan penulis, perkembangan yang lambat pada fisik dan mental merupakan ciri utama anak down syndrome. Biasanya, keluarga akan memberikan reaksi berbeda-beda dan kebanyakan belum dapat menerima keadaan ini. Merasa sedih, rasa tak percaya, menolak, marah, perasaan tidak mampu dan juga perasaan bersalah.

Anak down syndrome sebagai generasi penerus bangsa perlu dikembangkan agar mandiri. Dengan teknik komunikasi khusus dapat membantu perkembangannya. Untuk itu penulis membuat kajian teoritis dan penagamatan pada seorang anak berkebutuhan khusus dengan mewawancarai orangtuanya. Untuk mengetahui apa yang dilakukan orangtua tersebut terhadap anaknya.

\section{METODOLOGI PENELITIAN}

Kasus di Timur Tengah dan Afrika Utara tersebut akan dianalisis dari kerangka hermeneutika Schleiermacher dan hermeneutika 
Gadamer. Hermeneutika adalah metode penafsiran yang dahulunya digunakan untuk memahami kitab suci. Hermeneutika dikembangkan menjadi salah satu pendekatan terhadap berbagai fenomena yang lebih mengandalkan subjektivitas penafsiran dibanding independensi objek. Terdapat beberapa jenis hermeneutika, salah satunya hermeneutika dari Friedrich Schleirmacher (1768-1834). Hermeneutika Schleiermacher menekankan bahwa kebenaran penafsiran hanya dimungkinkan jika penafsir mampu memahami teks sebaik pengarang teks tersebut. Dalam arti kata lain, penafsir harus memahami situasi sosiokultural, historis, biografis hingga psikologis si penulis teks. Hanya dengan itu, penafsir akan mampu memahami teks seutuhnya. Dalam penelitian ini, hermeneutika Schleiermacher digunakan untuk memahami "teks" yang diciptakan oleh fenomena di Timur Tengah dan Afrika Utara. Dalam hal ini peneliti akan mencoba "mengalami" fenomena di wilayahwilayah tersebut dari sudut pandang sosiokultural, biografis, historis, dan psikologis.

Hermeneutika berikutnya adalah dari Hans George Gadamer (1900-2002). Gadamer mengkritik Schleirmacher karena seharusnya teks bersifat produktif, bukan historis. Maka penafsiran hanya mungkin jika murni berdasarkan keadaan sosio-kultural, biografi, dan psikologi si penafsir. Bagi Gadamer, penafsiran ala Schleirmacher tidak hanya mustahil, tapi juga tidak bermanfaat. Kita sebaiknya tidak mengimitasi teks, melainkan justru memproduksi ulang menjadi pemikiran yang aktual dan segar. Hermeneutika Gadamer digunakan peneliti dalam memproduksi ulang pemikiran teks agar menjadi konklusi dalam artikel ini.

Untuk memperkuat konklusi, akan diambil teori dari John McManus tentang ciriciri media baru sebagai rujukan. McManus memaparkan adanya tendensi ke arah media baru yang bercirikan: 1) Teknologi yang dahulu berbeda dan terpisah seperti percetakan dan penyiaran sekarang bergabung. 2) Ada pergeseran dari kelangkaan media menuju media yang melimpah. 3) Ada pergeseran dari mengarah kepuasan massa audiens kolektif menuju kepuasan grup atau individu.4) Ada pergeseran dari media satu arah kepada media interaktif.

\subsection{Down Syndrome}

Dalam pengamatan penulis, orangtuanyalah yang selalu mewakili anak dalam berkomunikasi. Anak menjadi takut mengekspresikan ide-idenya. Bahkan orangtua dan kebanyakan orang sering menilai anak down syndromesebagai "sampah ataupun pembawa sial". Padahal jika dirawat dan diajarkan dengan komunikasi yang baik, mereka dapat berprestasi dan mandiri sehingga dapat membawa nama daerahnya.

Down Syndrome adalah suatu kondisi keterbelakangan perkembangan fisik dan mental anak yang diakibatkan adanya abnormalitas perkembangan kromosom (Susanto,2011: 47). Kromosom ini terbentuk akibat kegagalan sepasang kromosom untuk saling memisahkan diri saat terjadi pembelahan. Down syndrome 
merupakan kelainan kromosom yang dapat dikenal dengan melihat manifestasi klinis yang cukup khas. Kromosom merupakan serat-serat khusus yang terdapat di dalam setiap sel di dalam tubuh manusia, dimana terdapat bahanbahan genetik yang menentukan sifat-sifat seseorang. Selain itu,down syndrome disebabkan oleh hasil penyimpangan kromosom semasa konsepsi.

Anak cacat mental ditandai dengan lemahnya kontrol motorik, kurang kemampuannya untuk mengadakan koordinasi, tetapi dipihak lain masih bisa dilatih untuk mencapai kemampuan sampai ke titik normal. Tanda-tanda lainnya seperti membaca buku terlalu dekat ke mata, mulut selalau terbuka, untuk memahami sesuatu pengertian memerlukan waktu yang lama, mempunyai kesulitan sensoris, mengalami hambatan berbicara dan perkembangan verbalnya.

Doman mengungkapkan bahwa $15 \%$ orang tua yang mengetahui anaknya mengalami down syndrome akan kembali ke rumah dan tidak melakukan suatu program terapi. Sebanyak 35\% yaitu orang tua yang gigih tekadnya untuk ikut Program Perawatan Intensif. Sebanyak $50 \%$ orang tua akan kembali ke rumah, mendiagnosis anaknya, mendesain sebuah program untuk anaknya dan melaksanakan program itu dengan tingkat frekuensi, intensitas dan durasi yang berbedabeda dengan harapan memperoleh hasil yang sepadan dengan program itu.
Dari pendapat tersebut di atas dapat penulis simpulkan bahwa down syndrome adalah anak yang memiliki kelebihan kromosom sehingga intelektual dibawah rata-rata dan memiliki kelainan fisik. Kelainan pada anak down syndrome sangat jelas dan setiap anakdown Syndrome hampir memiliki wajah yang serupa.

Menurut Moh. Amin (1995) dalam Qaharana (2010: 23 - 24) menyebutkan karakteristik anak down syndrome menurut tingkatan adalah sebagai berikut:

a) Karakteristik anak down syndrome ringan Anak down syndrome ringan banyak yang lancar berbicara tetapi kurang pembendaharaan katanya. Mengalami kesukaran berpikir abstrak tetapi masih mampu mengikuti kegiatan akademik dalam batas-batas tertentu. Pada umur 16 tahun baru mencapai umur kecerdasan yang sama dengan anak umur 12 tahun.

b) Karakteristik anak down syndrome sedang Anak down syndrome sedang hampir tidak bisa mempelajari pelajaran-pelajaran akademik. Mereka umumnya dilatih untuk merawat diri dan aktivitassehari-hari. Pada umur dewasa mereka baru mencapai tingkat kecerdasan yang sama dengan umur 7 tahun.

c) Karakteristik anak down syndrome berat dan sangat berat

Anak down syndrome berat dan sangat berat sepanjang hidupnya akan selalu bertanggung pada pertolongan dan bantuan orang lain. Mereka tidak dapat memelihara diri, tidak dapat membedakan 
bahaya atau tidak,kurang dapat bercakapcakap. Kecerdasannya hanya berkembang paling tinggi seperti anak normal yang berusia 3 atau 4 tahun.

\subsection{Komunikasi Orangtua Kepada Anak}

Komunikasi adalah "proses mengubah perilaku orang lain" (Effendy,2001:9). Serta berbeda halnya dengan pendapat Joseph. A. Devito (1997) dalam Daryanto (2010:58) menyatakan bahwa :

"Hakikat dari sebuah proses komunikasi adalah hasil (output) dan manfaat (outcome) dari proses kegiatan komunikasi tersebut. Hasil menunjukkan bahwa pesan tersebut tanpa ada penyimpangan atau distorsi serta penerima pesan memberikan umpan balik (feedback) yang konsisten, selaras, atau serasi terhadap pesan yang disampaikan tersebut. Outcome menunjukkan pada besarnya manfaat (benefit) yang dirasakan oleh penerima pesan setelah pesan tersebut disampaikan".

Komunikasi merupakan suatu "bentuk kegiatan". Penyampaian pesan dari sumber pesan kepada penerima pesan. Oleh karena itu, komunikasi yang efektif dapat diartikan sebagai, suatu kegiatan komunikasi yang dapat mencapai hasil(output) sebagaimana yang diharapkan (target) dan termuat dalam pesan tersebut serta dapat memberikan kemanfaatan (benefit) yang besar kepada sasaran komunikasi atau penerima pesan (Daryanto, 2010:59).

Komunikasi berperan dalam kehidupan. Melalui komunikasi antar pribadi, orang dapat mengenal dirinya dan diri orang lain. Dengan komunikasi dapat saling memahami.

Dalam kaitannya dengan orangtua sebagai pemelihara dan pendidik anaknya, sangat berperan dalam berkomunikasi dengan anakanaknya, apalagi yang menderita down syndrome. Dengan harapan dapat mengubah perilaku anaknya. Tujuan komunikasi ini kemudian dikaitkan dengan teori ABA.

\subsection{Teori Applied BehaviourAnalysis(Aba)}

Teori ini digunakan untuk mengubah perilaku menyimpang pada orang dengan gangguan perkembangan dan penyakit mental. Prinsip-prinsip dasar perilaku dapat digunakan dalam lingkungan keluarga dengan cara yang sama pada lingkungan sosial untuk mengontrol perilaku anak down syndrome. Mengatur masalah kebiasaan dan mengajarkan kemampuan yang diperlukan untuk menerimacara komunikasi dan perilaku dalam keluarga tersebut.

Applied Bahavior Analysis atau ABA biasanya diterapkan atau digunakan pada anak dengan prilaku autis. Applied Bahavior Analysis (ABA) ditemukan oleh seorang psikolog Amerika, Universitas California Los Angeles, Amerika Serikat, Ivar O. Lovaas (Handojo, 2003:50), Sekitar tahun 1970. Beliau memulai eksperimen dengan cara mengaplikasikan teori B.F. Skinner, yaitu Operant Conditioning. Di dalam teori ini disebutkan bagaimana stimulusrespons (S-R) yang benar diperkuat dan akhirnya mendominasi hubungan stimulus-respons yang tidak benar. Penguatan tersebut bisa berbentuk positif maupun negatif. Penguatan positif dapat berbentuk pujian, sedangkan penguatan negatif dapat berbentuk hukuman. 
Secara prinsip, teori Applied Bahavior Analysis (ABA) memiliki 3 langkah yang harus diperhatikan, yaitu:

1. Terstruktur, yakni pengajaran menggunakan teknik yang jelas.

2. Terarah, yakni ada kurikulum jelas untuk membantu mengarahkan pendidik atauterapis.

3. Terukur, yakni keberhasilan dan kegagalan menghasilkan perilaku yang diharapkan,diukur dengan berbagai cara, tergantung kebutuhan.

Menurut Ing Darta R Wijaya, (2005:57), Applied Behavior Analysis (ABA) menggunakan teknik "discrete trials", yaitu seluruh tugas (target-target perilaku) dipecah dalam tahap kecil. Belajar "diskret" berarti memerinci keterampilan ke dalam komponen kecil, mengajarnya sampai terkuasai, memberi pengulangan, menyediakan prompt (bantuan), menghilangkan ketergantungan dan pemberian pujian (reinforcerment).

Pada intinya Applied Behavior Analysis (ABA), memiliki tiga tahapan yaitu stimulus (intruksi), respon individu (perilaku) dan konsekuensi (akibat perilaku). Intruksi yang diberikan haruslah dimulai dari hal yang mudah menuju ke yang lebih sulit. Intruksi itu pun harus terstruktur, terarah dan terukur. Ketika melaksanakan teknik ini, seorang pendidik atau terapis harus konsisten memberikan stimulus, respon dan konsekuensi yang diberikan.

Dalam sebuah pengalaman, banyak kemampuan prasyarat (tingkah laku) yang diperlukan untuk menerima perawatan dari pasangan orang tua terhadap anak penderita down syndrome (contohnya kemampuan untuk berbicara, duduk, bersikap dan toleransi terhadap orang lain yang diluar dari keluarga) dapat dipelajari di rumah atau lingkungan sekolah oleh instruktur atau orang tua yang benar-benar mengenalnya dalam komunikasi berdasarkan prinsip tingkah laku. Oleh sebab itu, komunikasi orang tua yang digunakan juga harus dilakukan oleh pihak keluarga penderita down syndrome, fokus dalam mengidentifikasi variabel yang dapat menyebabkan masalah tingkah laku dalam kehidupan sehari-hari dan memodifikasi tingkah laku tersebut untuk menganjurkan yang baik, untuk hasil jangka panjang.

Perubahan rutinitas pada anak down syndrome membuat stres dan sangat sensitif pada lingkungannya (khususnya lingkungan yang kurang familiar), mungkin sangat sulit jika tidak ada dukungan keluarga dan kesabaran orang tua dalam memberikan pemahaman terhadap anak down syndrome. Orang tua dapat memodifikasi rutinitasnya dan dapat membuat perubahan supaya interaksi dapat berjalan semulus mungkin. Modifikasi ini meliputi :

a) Memanfaatkan orang yang dekat dengan anak

b) Mempelambat langkah dalam segala sesuatunya

c) Menggunakan alat bantu lihat misal gambar dan menggunakan instruksi yangsederhana

d) Menjelaskan hal yang akan dilakukan sebelum memegangnya

e) Jika memungkinkan, biarkan anak memegang alat dan bahan 
f) Meminimalkan gangguan

\section{PEMBAHASAN}

\subsection{Komunikasi Orangtua Dan Anak Down Syndrom}

Ada lima strategi pengkondisian operan yang dapat dipakai untuk menigkatkan perilaku anak berkebutuhan khusus yang diharapkan yaitu :

1) Pemilihan penguatan yang efektif

Tidak semua penguatan akan sama efeknya bagi anak. Analisis perilaku terapan menganjurkan agar orang tua mencari tau penguat apa yang paling baik untuk anak, teknik mengindividualisasi penggunaan penguat tertentu.

Untuk mencari penguatan yang efektif bagi seseorang anak, disarankan untuk meneliti apa yang dilakukan dan memotivasi anakdown syndrome di masa lalu. Penguatan alamiah seperti pujian lebih dianjurkan ketimbang penguat imbalan materi, seperti uang, permen dan mainan.

2) Menjadikan Penguatan Kotingen dan tepat waktu

Agar penguatan dapat efektif, orang tua harus memberikan hanya setelah anak down syndrome melakukan perilaku tertentu. Jika anak menyelesaikan perilaku sasaran seperti bisa makan sendiri tapi orang tua tidak memberikan waktu bermain pada anak, maka anak itu mungkin akan kesulitan membuat hubungan kontingensi.

3) Memilih Jadwal Penguatan Terbaik
Menyusun jadwal penguatan menentukan kapan suatu respon akan diperkuat.

4) Menggunakan Perjanjian

Perjanjian adalah menempatkan kontingen penguatan dalam tulisan. Jika muncul problem dan anak tidak bertindak sesuai harapan, orang tua dapat merujuk anak pada suatu perjanjianyang mereka sepakati.

5) Menggunakan Penguatan Negatif Secara Efektif

Dalam penguatan negatif, frekuensi respon meningkat karena respon tersebut menghilangkan stimulus yang dihindari. Misalnya orang tua mengatakan " rian, jangan main selagi makan, tidak ikut jalan-jalan jika masih main-main saat makan". Ini berarti orang tua menggunakan penguatan negatif.

Berkomunikasi sangatlah diperlukan baik dalam kehidupan pribadi seseorang, maupun perusahaan dan organisasi, supaya langkah-langkah yang akan dilakukan demi kepentingan akan terarah dan mencapai tujuan yang diinginkan. Teknik komunikasi merupakan panduan dari perencanaan komunikasi dan manajemen komunikasi untuk mencapai suatu tujuan. Untuk mencapai tujuan tersebut teknik komunikasi harus dapat menunjukkan bagaimana operasionalnya secara taktis harus dilakukan, dalam arti kata bahwa pendekatan bisa berbeda sewaktu-waktu tergantung dari situasi dan kondisi ( Effendi, $2008: 32$ ).

Sementara orangtua yang tidak banyak pengetahuan mengenai bagaimana cara merawat dan berinteraksi dengan anak penderita down 
syndrome akan memiliki sikap yang lebih dominan keras dan menutupi diri pada kehidupan sosial. Karena takut anaknya dicemooh, jadi bahan hinaan para tetangga maupun masyarakat sekitar. Tidak banyak dari para orang tua yang mengalami tingkat depresi ringan hingga berat dan akhirnya akan muncul tindakan untuk mengurung, tidak acuh, bahkan sampai menelantarkan anak tersebut. Tetapi banyak juga orang tua yang berhasil dalam mendidik dan merawat anak tersebut, Sebenarnya kendala dan hambatan yang sering dihadapi bukan terletak pada anak penderita down syndrome melainkan terletak pada berapa besar rasa menerima orang tua terhadap kondisi anak yang terlahir secara down syndrome".

Proses komunikasi menjadi sangat penting karena menjadi dasar interaksi. Dan tak ada satu pun manusia/individu yang dapat menghindar dari interaksi dan komunikasi. Karena telah menjadi kebutuhan yang sama sekali tidak dapat di hindarkan dalam aspek apapun. Sepertidisampaikan (Komarudin, Schermerhorn, Hunt \& Osborn, Koontz \& Weihrich)dalam (Daryanto, 2010:147) mengatakan bahwa :

"Komunikasi merupakan sebuah proses penyampaian pikiran atau informasi dari seseorang kepada orang lain melalui suatu cara tertentu sehingga orang lain tersebut mengerti betul apa yang dimaksud oleh penyampai pikiran-pikiran atau informasi".

Komunikasisebagai usaha penyampaian pesan antarmanusia.Tujuan komunikasi adalah untuk mencapai kesamaan makna, objeknya disini manusia. Dalamsetiap tindakan komunikasi akan menimbulkan efek, yang mencakup efek komunikasikognitif (berpikir), afektif (bersikap),dankonatif (bertingkah laku) (Cangara, 2012:1). Keberadaan komunikasidalam kehidupan dikatakan sangat penting karena dapat menjadi salah satu ungkapan, menyampaikan perasaan dari orang yang satu dengan yang lainnya, kelompok yang satu dengan yang lainnya. Seseorang menyatakan keinginannya melalui komunikasi.

Proses komunikasi terhadap anak penderita down syndrome dan anak yang normal sudahlah tentu berbeda. Para orang tua yang memiliki anak penderita down syndrome dalam melakukan komunikasi dengan anaknya haruslah memiliki strategi komunikasi yang tertentu demi tercapainya pesan yang akan diterima oleh anak tersebut. Pada dasarnya pola komunikasi yang dilakukan dengan penyandang Down syndrome tentu saja menggunakan bahasa yang sesuai agar mampu mengerti apa yang disampaikan oleh seseorang. Sesuai dengan fungsinya, bahasa merupakan alat komunikasi yang digunakan seseorang untuk berhubungan dengan orang lain. Bahasa merupakan alat pergaulan. Penggunaan bahasa menjadi efektif sejak seseorang individu berkomunikasi dengan orang lain. Biasanya anak down syndrome memulai mengembangkan bahasanya dimulai dengan meniru suara atau bunyi tanpaarti dan diikuti dengan ucapan atau satu suku kata, dua suku kata, menyusun kalimat sederhana, danseterusnya. Dengan menggunakan bahasa inilah, penderita down syndrome berhubungan sosial sesuai dengan tingkat perilaku sosialnya. 
Karena kurangnya pengetahuan dalam masyarakat mengenai cara berkomunikasi dan berinteraksi dengan anak penderita down sndyromebanyak orang tua yang mengesampingkan anak-anak berkebutuhan khusus tersebut. Namun tidak sedikit pula orang tua yang telah berhasil dalam merawat dan mengajarkan anak-anak yang menderita down sndyrome menjadi layaknya anak normal dan mampu menuai prestasi dan kebanggaandilingkungannya.Melihat fenomena ini, maka peneliti menilai bahwa peranan orang tua yang memiliki anak penderita down sndyrome ini merupakan hal yang menarik untuk diteliti. Karena dapat mengetahui strategi komunikasi yang orang tua gunakan dalam berinteraksi dengan anak berkebutuhan khusus tersebut yang dimana masih banyak masyarakat umum belum mengetahuinya

Dalam prakteknya, orang tua memberikan intruksi atau perintah yang jelas tentang perilaku yang diinginkan (misalnya "ambil sapu"), jika anak merespon dengan benar dengan menunjukkan perilaku yang tidak berulang maka hal tersebut berhasil. Namun jika anak tidak merespon dengan benar maka orang tua memberikan intruksi yang lembut dan berkomunikasi lebih intim dengan cara meletakkan tangan anak tersebut disapu dan memberikan perintah untuk mengulangi aktivitas tersebut. Harapannya adalah bahwa anak tersebut akhirnya akan belajar untuk menggeneralisasikan respon yang benar.

Dalam kajian ini penulis mengamati Amel anak yang berkebutuhan khusus, serta melakukan wawancara dengan orangtuanya, dan hasilnya adalah sebagai berikut:

Ketika mewawancarai orang tua Amelsebagai anak yang dilahirkan berkebutuhan khusus atau down syndrom, keduanya merasakan putus asa dan kecewa saat mengetahui anaknya menderita down syndrome. Sedih karena membayangkan anak ini pasti jadi bahan gujingan dan bulian orang lain. Sebagai masyarakat awam tidak tahu jikadown syndromeyaitu memiliki pola pikir dibawah anak normal".

Awalnya, kami mulai bertanya-tanya ketika Amel berusia 3 bulan kenapa Amel belum tengkurap?Kemudian kami amati Amel baru bisa merayap umur 5 bulan. Kamipun membandingkan dengan abangnya saatusia 9 bulan sudah bisa berjalan. Sementara mbakYunya usia 11 bulan bisa berjalan. Sementara Amel umur satu tahun belum bisa berdiri. Ketika Amel kami dudukkan diatas kursi beroda kenapa Amel mendorong mundur bukan maju.

Setelah melihat gejala-gejala itu, kami mulai berikhtiar. Rajin mendatangi tukang urut dan konsul kedokter. Kami mulaisadar ketika melihat gerakan tangannya yang kaku, bahwa buah hati kami ada kelainan. Dokter menyebutnya gangguan syaraf motorik.

Kami sangat cemas dan terus berusaha dengan pengobatan alternatifdan medis. Hati kami menjerit pilu manakala dokter di Yogyakarta mengatakan tidak ada obat, walau satu truk obat tak akanada gunanya. Dokter memberi harapan dengan terapi dan berlatih menggunakan walker alat bantu pegangantangan. Diharapkan nantinya Amel dapat berjalan walau 
tak sempurna. Kamipun tetapoptimis ananda tercinta suatu hari akan bisa berjalan.

Biasanya masalah dalam berkomunikasi, jika saat Amel bersikap agak keras dan mau menang sendiri. Kalau lagi tidak maujangan dipaksa. Hal ini dikarenakan ananda Amel meskipun secara usia ia sudah menginjakdewasa namun perilakunya masih seperti anak-anak, jika ia tidak mau di perintah tapi dipaksa maka responnya akan menangis layaknya anak kecil, kemudian Amel, biasanya susah dilarang sebagaikendala-kendala yang sering dihadapi”.

Komunikasi yang kami lakukan dengan melihat gerakan mulutnya jika masih kurang mengerti kami minta ulang. Jika Amel berbicara kami meresponnya dengan gerakan tangan atau menunjukkan suatu barang. Disamping itu kami tersenyum, mengangguk, dan bersalaman meskipun terkadang saya ada yang kurang mengerti maksudnya. Dengan adanya respon maka ia merasa dihargai.

Karena itu dalam berkomunikasi kami merasa tidak ada masalah, semua biasa saja. Terjadi komunikasi timbal balik. Hasil yang tampak, jika Amelberkomunikasi menggunakantelepon maka tidakmenyangkajika ananda Amel bermasalah. Kami tetap mengajak Amel pergi dalam setiap kegiatan keluarga, termasuk undangan apapun. Kami tidak menutupi Amel kepada orang lain dan lingkungan.

Pada usia 5 tahun Amel masuk ke Taman Kanak-kanak. Selanjutnya pada usia 7 tahun masuk SD, dan saat ini amel sudah di kelas 9 sebentar lagi akan tamat SMP. Semuanya sekolah umum bukan sekolah khusus. Kami selalu memberikan semangat, untuk itu ananda Amel seperti tidak ada masalah dia bisa menikmati dan tetap ceriah.

Hambatan lain biasanya ditimbulkan dari luar, karena anak-anak normal yang seumuran bahkan lebih dewasa darinya suka mencemooh dan tidak mau berkomunikasi apalagi berinteraksi. Hal ini juga terkadang membuat kami tidak mengizinkan Amelmain diluar. Dan keluar hanya saat sekolah dan bepergian saja.

Dalam lubuk hati kami yang terdalam, kamiterasa teriris, bagaimana tidak, seharusnya Ameldapat bermain dengan ceria, namun setiap hari ananda Amel hanya duduk dibangku sekolah tanpa pindah jika tidak dijemput. Belum lagi ulah teman-temannya yangterkadang menyakitkan, tidak memperdulikan, tidak mau berteman. Alhamdulillah ananda Amel sangat percaya diri, dia tidak peduli walau terkadang dia juga menangis karena ulah teman-temannya. Sebagai wanita, Ibunya tidak bisa menahan emosi, terkadang emosinya susah dikendalikan tidak jarang istri saya mendatangi guru yang kurang mengerti dan bahkan menyemprot anakanak yang menyakitkan hati ananda Amel.

Saat ini kenyataannyaAmel belum juga bisa berjalan. Kamisemakin sedih, hampir putus asa membayangkan ananda Amel, bagaimana jika orang tuanya sudah tiada. Bagaimana nasibnya kedepan. Saat ini kami sedang bimbangakan melanjutkan sekolah SLTA kemana ananda amel, home scholl belum ada dikota ini. Kami melihat ada bakat musik dan bernyanyi serta bakat bahasa Inggris pada ananda Amel. Namun, dikota Baturaja ini tidak 
ada sekolahnya atau kursusmusik yang representatif yang bisa dimasuki. Kami berkomunikasi terus memberikan semangat agar ananda Amel bisa mandiri, alhamdulillah ananda Amel tetap bersemangat ingin sekolahbahkan sampai keperguruan tinggi, saya berharap pada suatu saat Amel akan menjadi sarjana komunikasi.

Menurut kami, Amel cukup cerdas, namun perlu kesabaran mengajarkan sesuatu padanya. Amel mudah menangkap hal-hal yang bersifat hafalan, tetapi lumayan sulit untukmatematika. Amel suka menyanyi,dari kecil kami mengajarkan budi pekerti dan akhlak yang baik. Amel sangat perasa tidak boleh ada keributan atau pertengkaran dirumah karena itu akan membuatnya sedih dan marah. Amel sangat sayang kepada kami, saudara dan temantemannya.Amel bukanlah anak pendendam dan suka menolong. Hal ini memang kami tekankan akanhidup bersama, saling tolong menolong, saling menghormati, kami selalu mengajak Amel untuk shalat berjamaah, mengaji dan membaca kisah-kisah yang baik.

Kami perhatikan Amel mempunyai kelebihan pada hapalan/bicara, bernyanyi danberbicaradalam bahasa Inggris. Ini adalah data-data tentang Amel. Namanya Amelia Choirunnisa, dilahirkan di Baturaja, 30 Juni 2001, Agama : Islam. Pendidikan : SMP kls 9. Hobby :bernyanyi, korespondensi melalui elektronik media, bahasaInggris. Golangan darah : O. Anak ke tiga dari tiga bersaudara, punya kembaran tapi sudah meninggal dalam usia 3 bulan. Anak dari pasanganDarman Syafe'I, SE.M.Si dan Ismala Dewi, AR. BA.

Yang menjadi catatan penting, Amel dengan kebutuhan khususnya dapat sekolah pada sekolah umum hingga SMP, pandai bernyanyi dan berbahasa Inggris. Hal ini berkat kesabaran ibu dan bapak Amel. Selalu mengajak Amel untuk berinteraksi secara terbuka.

\subsection{Beberapa Anak Down Syndrom Yang Berprestasi}

Melihat dan mencari di Internet, berikut beberapa anak down syndrome yang berprestasi diantaranya adalah:

\section{Stephanie Handoyo,}

anak penderita downsyndrome berusia 18 tahun yang berhasil memecahkan rekor MURIsebagai pemain piano yang mampu membawakan 23 lagu berturut-turut dalam sebuah acara musik di Semarang, Jawa Tengah

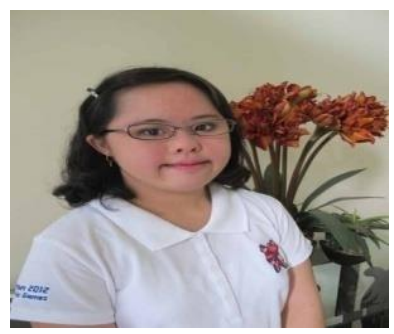

Dokumentasi Gambar The Jakarta Post, 19 Juli 2012

\section{Katie Henderson,}

Seorang fashion illustrator berusia 30 tahun yang terlahirdown syndrome, namun tidak membuatnya berhenti dan patah semangat dalam berkarir. 


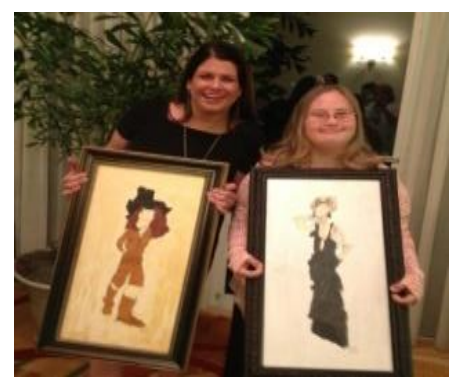

DokumentasiGambar misskatieskreation.com

\section{Reviera Novitasari,}

seorang anak perempuanyang berhasil menunjukkan bahwa ia berbeda dengan anak-anakdown syndrome lainnya dengan berhasil mendapatkan medali perunggu renang 100 meter gaya dada pada kejuaraan renang internasional di Canberra, Australia, 11-13 April 2008.

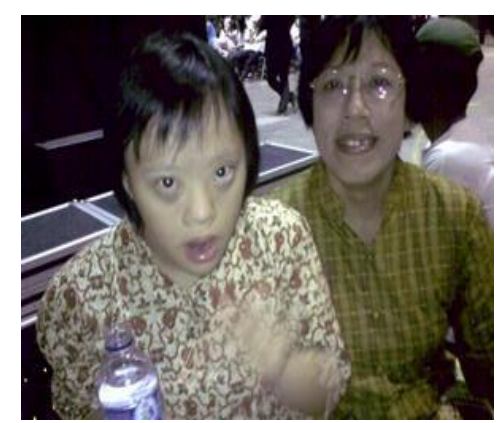

Dokumentasi Gambar kompas.com

\section{Samuel Santoso,}

seorang anak berkebutuhan khusus yang sukses memperoleh penghargaan dari MURIsebagai pelukis penyandang downsyndrome yang pertama menggelar 50 karya lukisan dalam pameran lukisannya.

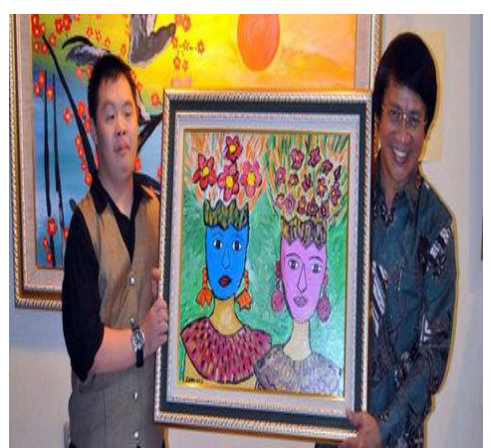

Dokumentasi Gambar kapanlagi.com

\section{Michael Rosihan Yacub,}

remaja berusia 20 tahun yang berhasil meraih rekor MURI dengan menjadi satusatunya pegolf muda yang memiliki downsyndrome dan bertanding melawan para pegolf normal. Ia mampu mendalami olahraga golf yang membutuhkan konsentrasi tinggi dengan IQ hanya 35.

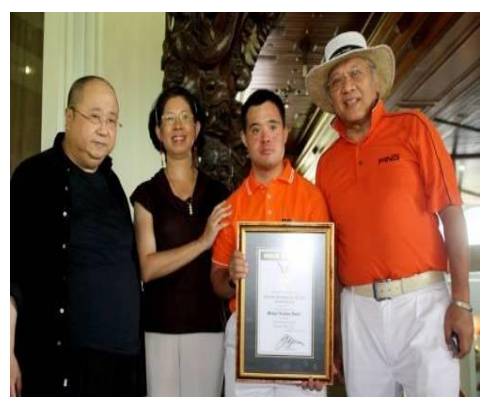

DokumentasiGambar indonesia.sinchew.com.my

\section{Lauren Potter,}

Anak perempuan penyandang down syndrome dari Amerika yang berhasil menjadi artis dan berperan dalam beberapa film besar, seperti Glee.

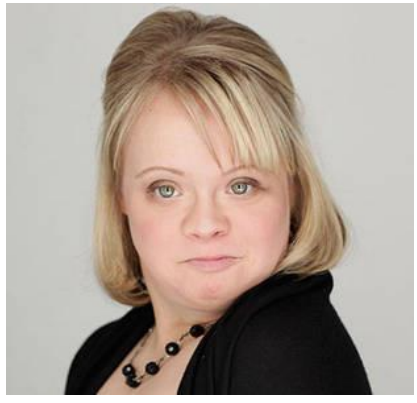

Dokumentasi Gambar wetpaint.com

\section{Tim Harris,}

Remajalaki-laki yang memiliki down syndrome, namun berhasil membangun bisnis restorannya sendiri. 


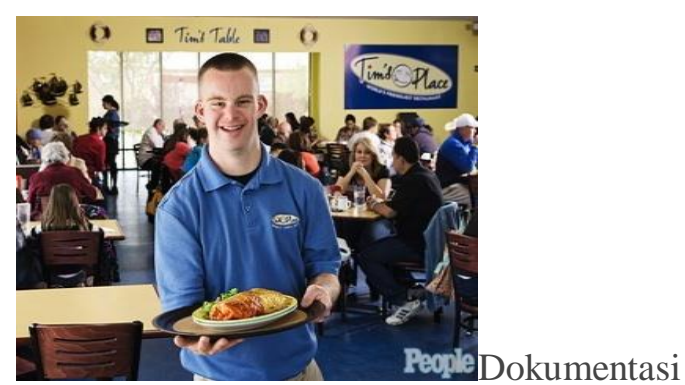

Gambar people.com

\section{SIMPULAN}

1. Downsyndrome bukanlah penghalang bagi mereka untuk berprestasi. Dengan pendekatan yang tepat, semua anak dapat berkarya sesuai dengan potensi mereka masing-masing.

2. Komunikasi yang digunakan oleh orangtua menghadapi anak berkebutuhan khusus menggunakan komunikasi verbal dan nonverbal seperti berbicara sambil menggerakan tangan atau bagian tubuh lainnya. Berkomunikasi dengan kasihsayang dan kesabaran.

3. Orang tua berperan dalam mendukung perkembangan perilaku anak penderita downsyndrome, dukungan material dan non material. Anak penderita downsyndrome dominan bersikap keras dan mengalami kesulitan dalam berkomunikasi.Berkomunikasi diperlukan perilaku terapan agar dapat direspon dan berperilaku positif pada anak tersebut.

4. Orangtua berkomunikasi dan berinteraksi dengan anak penderita down syndrome harus bersikap lebih lembutnamun tegas dalam menghadapinya dan mengajarkan sesuatu dengan harapan untuk mendapatkan perilaku yang postif .

Anak keterbelakangan mental juga memiliki perasaandan butuh kasih sayang,sama halnya pada anak-anak normal lainnya.Seharusnya para orangtua lebih mengutamakan anak berkebutuhan khusus dan lebih memberikan dukungan serta kasih sayang, karena tidak mustahil anak berkebutuhan khusus bisa menjadi lebih sukses dari anak yang normal jika diberikan pendidikan yang formal dan dukungan dari berbagai pihak. Anak-anak berkebutuhan khusus juga memiliki hak wajib atas perhatian dan dukungan keluarga maupun orang-orang terdekat, karena dengan cara seperti itulah yang mampu membangkitkan semangat hidup mereka agar tidak merasa tertekan akan keadaan hidup yang terjadi pada diri mereka. Disarankan agar pemerintah memperhatikan keberadaan anak berkebutuhan khusus. Dengan mengadakan fasilitas arena bermain. Dengan demikian anak bebas beraktivitas.

\section{DAFTAR PUSTAKA}

Briggs, Asa \& Burke, Peter. 2006. Sejarah Sosial Media: Dari Gutenberg sampai Internet. Terjemahan A. Rahman Zainuddin. Yayasan Obor Indonesia.Jakarta.

Cangara, Hafied. 2014. Edisi kedua Pengantar Ilmu Komunikasi. Jakarta: Rajawali Pers.

Daryanto, 2010, Ilmu Komunikasi, cetakan I, Bandung: Satu Nusa 
Effendy, Onong Uchjana. 2013. Ilmu Komunikasi Teori dan Praktek. Bandung : PT Remaja Rosdakarya.

Effendy, Onong Uchjana.2008. Dinamika Komunikasi. Bandung: PT Remaja Rosdakarya.

Handoyo, 2003, Pengantar Immunoasai, Surabaaya: Universitas Airlangga.

Hery Susanto, Agus. 2011. Genetika. Jakarta: Graha Ilmu.

Hurlock, Elisabeth. 2006. Psikologi Perkembangan Edisi Kelima. Jakarta : Erlangga.

Moleong, Lexy. 2001. Metode Penelitian Kualitatif Edisi Revisi. Bandung: Remaja Rosdakarya.

Afriyana Qaharana .2010. Melatih Motorik Anak Down syndrome dengan Metode Persiapan Menulis di TK Pemata Bunda Surakarta.Skripsi.

http://ibudanmama.com/topikhangat/10anaksyndrome-yang-menakjubkan-dunia/ 